\title{
PIOTR RAŹNIAK
}

Uniwersytet Pedagogiczny w Krakowie, Polska

Pedagogical University of Krakow, Poland

\section{SŁAWOMIR DOROCKI}

Uniwersytet Pedagogiczny w Krakowie, Polska

Pedagogical University of Krakow, Poland

\section{ANNA WINIARCZYK-RAŹNIAK}

Uniwersytet Pedagogiczny w Krakowie, Polska

Pedagogical University of Krakow, Poland

\section{Odporność na kryzys gospodarczy miast petniacych funkcię kontrolno-zarządzzq w Europie Środkowo-Wschodniej}

\section{Resistance of Cities Performing Command and Control Functions in Central and Eastern Europe to the Economic Crisis}

\begin{abstract}
Streszczenie: Artykuł ukazuje przestrzenne rozmieszczenie największych firm w Europie Środkowo-Wschodniej, które pełnią funkcję kontrolno-zarządczą miast. Na podstawie ich przychodów ze sprzedaży i zysków określono odporność funkcji kontrolno-zarządczej na potencjalny kryzys głównego sektora kreującego tę funkcję. Aby tego dokonać, opracowano wskaźnik Centrum Ekonomicznego Europy ŚrodkowoWschodniej (CEEŚW). Przeprowadzone badania wykazały, że najbardziej odporne na kryzys gospodarczy dominującego sektora tworzącego funkcje kontrolno-zarządcze są Warszawa, Praga i Budapeszt. Funkcję kontrolno-zarządczą miast w Europie Środkowo-Wschodniej tworzą przede wszystkim firmy sektora konsumenckiego i transportowego oraz produkcyjnego. Zauważono wpływ krajów UE 15 i byłego Związku Radzieckiego na przestrzenne rozmieszczenie CEEŚW. Główne miasta znajdują się w pobliżu granicy UE 15. Z drugiej strony największa ich liczba znajduje się w państwach, które po II wojnie światowej były osobnymi państwami, ale znajdowały się pod silnym wpływem politycznym i gospodarczym ZSRR. Z kolei miasta byłych republik radzieckich, które obecnie stanowią osobne państwa, miały niższą odporność na kryzys funkcji kontrolno-zarządczej. Jednocześnie położone są one w stosunkowo dużej odległości od krajów UE 15.
\end{abstract}

\begin{abstract}
The paper discusses the spatial distribution of the largest companies in Central and Eastern Europe that play a control and management role in cities. Their sales revenue and profits were used to determine the vulnerability of the control and management function to crisis in the main sector underpinning this function. The paper uses an indicator called "Economic Centre of Central and Eastern Europe" to examine this key issue. Research has shown that Warsaw, Prague, and Budapest are most immune to economic crisis in the dominant sector of their control and management function, which is driven in Central and Eastern European cities by the consumption, transportation, and production sectors. The spatial distribution of ECCEE index values is affected by the old 15 member states of the European Union and the former Soviet Union. Main ECCEE cities are located close to the old "EU 15" states. The largest number of ECCEE cities are located in countries that remained independent after World War II, although were strongly politically and economically affected by the Soviet Union. On the other hand, cities in former Soviet republics that are now independent states are less immune to crisis in their control and management function. At the same time, these countries are found relatively far away from the old $15 \mathrm{EU}$ member states.
\end{abstract}


Słowa kluczowe: globalizacja; miasta; regionalne funkcje kontrolno-zarządcze; siedziby zarządów; zróżnicowanie sektorowe

Keywords: cities; globalisation; headquarters; industry sectors; regional command and control functions; sectoral diversification

Otrzymano: 29 stycznia 2019

Received: 29 January 2019

Zaakceptowano: 20 maja 2019

Accepted: 20 May 2019

Sugerowana cytacja / Suggested citation:

Raźniak, P., Dorocki, S., Winiarczyk-Raźniak, A. (2019). Odporność na kryzys gospodarczy miast pełniących funkcję kontrolno-zarządczą w Europie Środkowo-Wschodniej. Prace Komisji Geografii Przemysłu Polskiego Towarzystwa Geograficznego, 33(2), 45-58. doi: 10.24917/20801653.332.4

\section{WSTĘP}

Wiele miejsca w literaturze światowej poświęcono badaniom miast pod kątem zlokalizowanych w nich siedzib zarządów korporacji i ich wpływu na siłę gospodarczą tych miast (Alderson, Beckfield, 2004; Taylor i in., 2009; Kilar, 2015, Raźniak, Winiarczyk-Raźniak, 2015; Csomós, 2017; Derudder i in., 2018; Raźniak, Dorocki, Winiarczyk-Raźniak, 2018a). Od lat siedemdziesiątych XX wieku korporacje transnarodowe stają się coraz ważniejsze w globalnej gospodarce, a wiele z nich zmieniło lokalizację siedziby swojego zarządu (Csomós, Derudder, 2014). S. Sassen (2006) twierdzi, że w największych miastach zlokalizowane są nie tylko siedziby zarządów największych korporacji, ale również mniejsze firmy o wysoce wyspecjalizowanych funkcjach. Natomiast funkcje kontrolno-zarządcze są relokowane do ośrodków subregionalnych i regionalnych.

Miasto globalne nie jest przestrzennie ograniczoną jednostką, lecz złożonym organizmem, na którego terenie zachodzą procesy w skali międzynarodowej. Tego typu ośrodek to nie tylko kolejne miasto w tradycyjnej hierarchii miasto - region - kraj. Ten rodzaj miasta jest bardziej zorientowany na procesy globalne niż na procesy lokalne i krajowe (Sassen, 2016). Z drugiej strony światowe spowolnienie gospodarcze mniej dotknie miasta posiadające wielkie korporacje reprezentujące wiele sektorów, ponieważ w przypadku kryzysu np. dominującego sektora w mieście pozostałe sektory są w stanie stawić opór kryzysowi i zapewnić pewien stopień stabilności w danym mieście. Stąd też miasta o silnie zróżnicowanej gospodarce są w stanie przetrwać spowolnienie w lokalnie dominującym sektorze gospodarki. Można zatem rozważać odporność funkcji kontrolno-zarządczej miasta na ewentualny kryzys głównego sektora tworzącego tę funkcję w mieście (Raźniak, Dorocki, Winiarczyk-Raźniak, 2017).

Dywersyfikacja gospodarki jest istotnym elementem stabilizacji i wzmocnienia regionów, co jest szczególnie istotne w przypadku kryzysu ekonomicznego (Masik, 2016). Koncepcje funkcji kontrolno-zarządczej miast (Csomós, 2013), miasta globalnego (Sassen, 1991) i miasta światowego (GaWC) opisują miasta za pomocą różnych wskaźników, ale nie biorą pod uwagę stopnia odporności miast na potencjalny kryzys tych funkcji. Można założyć, że miasto mające na swoim terenie duże korporacje i charakteryzujące się silną funkcją kontrolno-zarządczą niekoniecznie jest przygotowane na przypadek kryzysu tej funkcji. Funkcja kontrolno-zarządcza kreowana przez firmy należące do niewielkiej liczby sektorów może okazać się niestabilna w przypadku problemów korporacji ją tworzących. Z drugiej strony analizowana funkcja miast bazująca 
na wielu firmach i sektorach jest w stanie lepiej zrekompensować straty w części z nich lub problemy strukturalne w niektórych sektorach. W Europie Środkowo-Wschodniej zarówno warunki rynkowe, jak i kwestie polityczne należy rozpatrywać w świetle obecnych napięć politycznych między Rosją a Unią Europejską. Nie można wykluczyć eskalacji konfliktu i jego wpływu na politykę i handel. Może on wpłynąć na wyniki finansowe poszczególnych firm i całych sektorów gospodarki. Jeżeli dodatkowo zostaną nałożone sankcje na różne sektory, może to również odbić się na ekonomii miast w regionie poprzez obniżenie stóp wzrostu gospodarczego. W tym kontekście odporność na kryzys gospodarczy największych firm tworzących funkcje kontrolno-zarządcze staje się kluczowym elementem regionalnej i krajowej pozycji miast. W artykule podjęto próbę oceny zmian w randze miasta w obliczu poważnego kryzysu w dominującym sektorze gospodarczym miasta, który generuje jego funkcję kontrolno-zarządczą.

Kryzys rozumiany jest jako spadek wyników finansowych firm z najbardziej dochodowego sektora w mieście tworzących funkcję kontrolno-zarządczą, przez co przestają one pełnić ją w mieście. W celu określenia poziomu funkcji kontrolno-zarządczej miasta, przy wyłączeniu dominującego sektora, stworzono wskaźnik ilustrujący rangę miasta pod względem wyników finansowych korporacji według sektorów, a także stabilność tej rangi po usunięciu najważniejszego sektora. Ta metoda ma na celu dostarczenie informacji na temat potencjału funkcji kontrolno-zarządczej miasta, ale ukazuje także ścieżkę rozwoju gospodarczego lub specjalizacji ekonomicznej firm, które stworzyły analizowaną funkcję. Ponadto można założyć, że silna odporność miasta na kryzys gospodarczy wiąże się z wysokim stopniem powiązań międzynarodowych miasta, ponieważ straty finansowe generowane przez firmę $w$ jednym miejscu mogą zostać zrekompensowane przepływem środków z filii zlokalizowanej w innym mieście lub kraju.

Prowadzone są również badania nad miastami pod względem ich funkcji kontrolno-zarządczych w skali światowej (Csomós, 2013; Raźniak, Dorocki, Winiarczyk-Raźniak, 2015). Możliwe jest też zbadanie funkcji kontrolno-zarządczych miast w skali kraju, generowanych przez największe firmy zlokalizowane w danym kraju. P. Śleszyński (2015) twierdzi, że funkcje kontrolno-zarządcze mogą generować filie największych korporacji, których siedziba zarządu mieści się poza badanym krajem. Istnieją także badania nad odpornością całych gospodarek na kryzys gospodarczy w Europie Środkowej (Drobniak, 2017). Są też badania nad odpornością funkcji kontrolno-zarządczej miast na kryzys w dominującym sektorze w skali światowej (Raźniak, Dorocki, Winiarczyk-Raźniak, 2017), kontynentalnej (Dorocki, Raźniak, Winiarczyk-Raźniak, 2019) i jednego kraju (Raźniak, Dorocki, Winiarczyk-Raźniak, 2018b).

Szczególnie ważne wydają się badania nad powiązaniami biznesowymi istniejącymi między wiodącymi firmami. Dotyczy to zarówno ich struktury własnościowej, jak i powiązań między przedsiębiorstwami. We współczesnej gospodarce światowej badania nad funkcją kontrolno-zarządczą miast są ważne w odniesieniu do ich rozmieszczenia geograficznego (Śleszyński, 2018). Biorąc pod uwagę historię polityczną Europy Środkowo-Wschodniej oraz jej związek z procesami globalizacji, pozostaje ona wyjątkowym regionem, w którym wiele firm działających w tej części świata jest regionalnymi oddziałami dużych korporacji. Od lat dziewięćdziesiątych XX wieku następują duże inwestycje firm zagranicznych, które często przejmują ponad $50 \%$ udziałów (Zdanowska, 2017). Dlatego decyzje strategiczne dotyczące kluczowych funkcji firm podejmowane są poza regionem, w którym one działają, mimo że są one wymienione 
w raporcie Deloitte Central Europe Top 500. Jednakże kierownictwo regionalnych filii zlokalizowanych w Europie Środkowo-Wschodniej może mieć moc decyzyjną na poziomie lokalnym i regionalnym. Firmy te mogą zatem tworzyć regionalną i lokalną funkcję kontrolno-zarządczą. Na przykład decyzja o zamknięciu zakładu lub firmy podjęta przez zarząd korporacji (poza badanym regionem) może silnie wpłynąć na stabilność regionalnej funkcji kontrolno-zarządczej w mieście. W przypadku firm, których głównym udziałowcem jest firma spoza Europy Środkowo-Wschodniej, zachodzi realne zagrożenie transferu środków z dobrze prosperujących spółek-córek na rynku lokalnym do spółek-matek w przypadku ich trudności finansowych. Tego typu sytuacja miała miejsce np. w systemie bankowym w 2008 roku, kiedy zagraniczne banki wyprowadzały środki ze swoich filii zlokalizowanych w Europie Środkowo-Wschodniej, aby ratować wyniki finansowe swoich central. Dlatego ważne jest to, aby badać miasta nie tylko pod kątem wyników finansowych kluczowych korporacji, ale także pod względem stabilności funkcji kontrolno-zarządczej, ponieważ decyzje strategiczne bardzo często zapadają poza Europą Środkowo-Wschodnią.

Celem badania w tym kontekście jest określenie stopnia odporności funkcji kontrolno-zarządczych miast w Europie Środkowo-Wschodniej na kryzys w głównym sektorze gospodarki oraz przy zróżnicowaniu sektorowym firm tworzących funkcję kontrolno-zarząd czą.

\section{ŹRÓDŁO DANYCH I METODY}

Na podstawie raportów firmy Deloitte dokonano analizy wyników finansowych największych firm zlokalizowanych w Europie Środkowo-Wschodniej w latach 2008 i 2015 (Deloitte, 2018). Raporty wyszczególniają firmy, które mają swoje oddziały w co najmniej trzech krajach. Potencjał ekonomiczny tych firm można zatem rozpatrywać zarówno w skali międzynarodowej, jak i krajowej. Raporty przedstawiają 500 największych firm pod kątem ich przychodów ze sprzedaży, jednakże na liście nie są notowane banki i firmy ubezpieczeniowe. Znajdują się one w osobnym spisie zawartym w tych samych raportach, po 50 banków i 50 firm ubezpieczeniowych. Wydaje się, że nie można rozpatrywać funkcji kontrolno-zarządczej miast i jej odporności na kryzys bez tych sektorów, zwłaszcza w przypadku spowolnienia gospodarczego z 2008 roku. W związku z tym 50 banków i 50 firm ubezpieczeniowych zostało dodanych do listy 500 firm i powstała lista 600 największych firm w Europie Środkowo-Wschodniej. Deloitte bierze pod uwagę 18 krajów: Albanię, Bośnię i Hercegowinę, Bułgarię, Chorwację, Czechy, Estonię, Kosowo, Litwę, Łotwę, Macedonię, Mołdawię, Polskę, Rumunię, Serbię, Słowację, Słowenię, Ukrainę i Węgry. Nie ma w zestawieniu Rosji i Białorusi, ponieważ - jak twierdzą autorzy raportów - brakuje danych z tych krajów lub są one niewiarygodne (Deloitte, 2018).

Analizowana lista $500+100$ firm nie do końca pokazuje największe firmy regionu i może zawierać nadreprezentację jakiegoś sektora. W tym celu dokonano standaryzacji wartości przychodów ze sprzedaży i dochodu netto w ogóle 600 firm, poprzez obliczenie udziału dla poszczególnych firm, gdzie wartość max = 100, a następnie obliczono wartości średniej z obliczonych wartości.

$$
s_{\text {top }}=\frac{\left(\frac{x}{x_{\max }} 100\right)+\left(\frac{y}{y_{\max }} 100\right)}{2}
$$


gdzie:

$x$ - wartości przychodów ze sprzedaży,

$y$ - wartości dochodu netto.

Na podstawie $s_{\text {top }}$ nadano poszczególnym firmom rangę i do dalszej analizy wybrano 500 korporacji o największych wartościach. Zastosowana metoda, jak i wykorzystane w niej zmienne, została zaczerpnięta z wcześniejszych analiz potencjału kontrolno-zarządczego miast (Raźniak , Dorocki, Winiarczyk-Raźniak, Płaziak, Szymańska, 2017; Raźniak, Dorocki, Winiarczyk-Raźniak, 2018a). Analizowane firmy zostały zakwalifikowane przez Deloitte do dziewięciu sektorów: bankowy (banking), biochemiczny, medyczny i opieki zdrowotnej (life sciences and health care), energii i surowców (energy and resources), konsumencki i transportowy (consumer business and transportation), nieruchomości (real estate), produkcyjny (manufacturing), publiczny (public sektor), technologii, mediów i komunikacji (technology media and telecommunications), ubezpieczeniowy (insurance). Lokalizacja danej firmy została określona na podstawie siedziby zarządu znajdującej się na terenie Europy Środkowo-Wschodniej. W światowych koncepcjach miast, takich jak world city (Globalization and World Cities, 2018), global city (Sassen, 1991), i funkcji kontrolno-zarządczych (Csomós, 2013) dane agregowane były do obszarów metropolitalnych, analogicznie postąpiono w niniejszym badaniu.

Wydaje się, iż stabilność miasta może przejawiać się również w jego odporności na pojawiające się kryzysy gospodarcze. Autorzy starają się odpowiedzieć na pytanie, jak zmieni się pozycja miasta względem innych miast w momencie głębokiego kryzysu dominującego sektora w danym ośrodku. Kryzys jest tutaj rozumiany jako spadek parametrów finansowych firm danego sektora, przez który należące do niego korporacje wypadają poza autorską listę największych 500 firm Europy Środkowo-Wschodniej. Do tego celu utworzono wskaźnik o nazwie Centrum Ekonomiczne Europy Środkowej, który ukazuje pozycję miasta względem wartości poszczególnych firm według sektorów oraz stabilność ich pozycji po wyłączeniu poszczególnych sektorów. W ten sposób otrzymano informację zarówno o kompleksowym rozwoju lub też specjalizacji, jak i o potencjale danego miasta. Wzięto pod uwagę miasta, w których znajdowały się siedziby zarządów reprezentujących co najmniej trzy sektory. Wykluczono ośrodki z dwoma i jednym sektorem, ponieważ w przypadku kryzysu jednego z nich potencjał miasta zmniejszyłby się w bardzo dużym stopniu, obniżając jego stabilność (Raźniak, Dorocki, Winiarczyk-Raźniak, Płaziak, Szymańska, 2016).

Następnie w celu porównania pozycji poszczególnych miast obliczono wartości standaryzowane oparte na wartości średniej dwóch normalizowanych wartości: przychodów ze sprzedaży oraz dochodu netto $(x)$ dla poszczególnych sektorów gospodarki (z) [2], a następnie dokonano ich zsumowania, otrzymując w ten sposób syntetyczny wskaźnik potencjału (SPI) dla poszczególnych miast [3].

$$
z=\sum \frac{x-\frac{\sum_{i=1}^{N} x_{i}}{N}}{\sqrt{\frac{\sum_{i=1}^{N}\left(x_{1}-\bar{x}_{1}\right)}{N}}}
$$




$$
S P I=\sum_{i=1}^{N} z_{S_{i}}
$$

gdzie:

$x$ - wartości przychodów ze sprzedaży oraz dochód netto dla poszczególnych sektorów gospodarki,

$S$ - sektory gospodarki,

$N$ - liczba miast w danym sektorze.

W celu weryfikacji, który z sektorów najsilniej wpływa na potencjał miasta, odjęto od sumy wartości standaryzowanych w 2012 roku wartość poszczególnych sektorów i sprawdzono, jak zmieniła się suma wartości standaryzowanych (z') dla danego miasta, uznając za 100\% sumę początkową [4]. W ten sposób otrzymano informację, które miasta mają najsilniejszą specjalizację (mają jeden najsilniejszy sektor) oraz jaki sektor jest najsłabszy. Im wynik po odjęciu danego sektora jest niższy (poniżej 100), tym większa istotność danego sektora w danym mieście. Natomiast im wynik po odjęciu wartości danego sektora jest wyższy (od 100), tym niższa pozycja danego sektora na tle ogółu analizowanych miast. Ogólnie miasta, które mają wysokie różnice pomiędzy wartościami minimalnymi i maksymalnymi, otrzymanymi po odjęciu wartości standaryzowanych dla poszczególnych sektorów, mają dużą specjalizację jednego sektora i niedorozwój pozostałych. Natomiast miasta, dla których różnica pomiędzy wartościami skrajnymi jest mała, rozwinęły się w sposób kompleksowy.

$$
z^{\prime}=\frac{S P I-z_{S}}{S P I} 100
$$

Następnie w oparciu o wartości standaryzowane oraz zmienność wartości otrzymanych po usunięciu poszczególnych sektorów $Z^{\prime}$ skonstruowano indeks stabilności $(I S)$. W tym celu wartość wskaźnika SPI podzielono przez wartość odchylenia standardowego $(S D)$ wartości otrzymanych po odjęciu poszczególnych sekcji ( $\left.z^{\prime}\right)$ [5]. Im wartość wskaźnika jest wyższa, tym wyższa wartość według wartości poszczególnych sektorów oraz większa stabilność (brak silnej specjalizacji) i równomierny rozwój wszystkich analizowanych sektorów gospodarki. Pokazuje on także, jak kryzys finansowy głównego sektora wpływa na wyniki finansowe miasta.

$$
I S=\frac{S P I}{S D_{z^{\prime}}}
$$

Na koniec, w celu dokonania podziału miast na klasy rozwoju, skonstruowano syntetyczny wskaźnik kompleksowego rozwoju sektorowego miast (CEEŚW). We wskaźniku tym ujęto indeks stabilności, liczbę sektorów oraz liczbę siedzib zarządów [6]. W oparciu o analizę głównych składowych obliczono procent zmiennej wyjaśnianej ogólnej wariancji zmiennych dla poszczególnych lat, które przyjęto za wagi przy obliczeniu wskaźnika CEEŚW. Analiza składowych głównych polega na wyznaczeniu nowych zmiennych (składowych głównych), będących kombinacją liniową zmiennych obserwowanych (pierwotnych). Dokładna analiza składowych głównych umożliwia wskazanie tych zmiennych pierwotnych, które mają duży wpływ na wartość poszczególnych składowych głównych, czyli tych, które tworzą grupę jednorodną. Składowa główna jest wówczas reprezentantem tej grupy. Kolejne składowe są wzajemnie ortogonalne 
(nieskorelowane), a ich liczba jest mniejsza lub równa liczbie zmiennych pierwotnych. Analiza głównych składowych jest jedną z metod analizy czynnikowej, która pozwala na identyfikację struktury dla jednego lub większej liczby czynników. Podstawy teoretyczne analizy składowych głównych można znaleźć na przykład w opracowaniach: D. Morrisona (1967), Z. Chojnickiego i T. Czyż (1978) lub J. Paryska i W. Ratajczaka (2002) oraz A.J. Maćkiewicza i W. Ratajczaka (1993).

gdzie:

$$
C E E S ́ W=\frac{I S * w_{(I S)}+S * w_{(S)}+Z * w_{(Z)}}{\sum w}
$$

$Z$ - liczba siedzib zarządów,

$S$ - liczba sektorów,

$I S$ - indeks stabilności.

Dokonując obliczeń, należy pamiętać, że nie można ich prowadzić wówczas, gdy wartość średnia dla wartości poszczególnych sektorów wynosi zero. Normalizacja została przeprowadzona jedynie w nawiązaniu do modelowego rozkładu normalnego, bez sprawdzania asymetryczności danych, który przyjęto jako model praktyczny. Dlatego należy brać pod uwagę tę kwestię przy analizie danych oraz starać się nie stosować normalizacji do rozkładów silnie skośnych.

Bazując na nowej liście największych firm Europy Środkowo-Wschodniej, posłużono się wartościami wskaźnika założonymi we wcześniejszych badaniach (Raźniak, Dorocki, Winiarczyk-Raźniak, Płaziak, Szymańska, 2017). Wyszczególniono tam Główne Centra Ekonomiczne Europy Środkowo-Wschodniej (wartość wskaźnika CEEŚW > 1), Centra Ekonomiczne Europy Środkowo-Wschodniej (CEEŚW 0,500-0,999) i potencjalne Centra Ekonomiczne Europy Środkowo-Wschodniej (CEEŚW < 0,499).

\section{Centra EKonomiczne Europy Środkowo-WschodniEJ}

W 2008 roku analizowane firmy miały swoją siedzibę w 125 miastach, a w 2015 roku w 156 ośrodkach miejskich. Liczba miast zmniejszyła się o jedno $(-0,8 \%)$ w czasie światowego kryzysu gospodarczego w 2008 roku. Znaczące zróżnicowanie lokalizacji siedzib odnotowano w latach 2012-2015, kiedy to liczba miast wzrosła o 25,8\%. Przeciwny trend zaobserwowano w przypadku lokalizacji największych światowych korporacji (Forbes Global 2000, 2018). Liczba miast z największymi korporacjami wzrosła o 7,9\% w latach 2008-2012, a następnie spadła o 5,4\% w latach 2012-2015. Proces dekoncentracji przestrzennej funkcji kontrolno-zarządczych dotyczył największych korporacji w Europie Środkowo-Wschodniej, podczas gdy koncentracja przestrzenna była obserwowana w skali światowej.

W analizie wpływu zmian strukturalnych na gospodarkę określono stabilność ekonomiczną funkcji kontrolno-zarządczej miast w czasie kryzysu. Najmniejsze różnice w poziomie rozwoju gospodarczego w oparciu o specjalizację sektorową i wyniki finansowe przedsiębiorstw odnotowano w przypadku Pragi, Warszawy, Lublany, Wilna, Zagrzebia i Trójmiasta. Jednak ostatnie cztery miasta charakteryzowały się niskimi znormalizowanymi wartościami, dlatego różnica wartości wywołana utratą dużego sektora gospodarki była niewielka. Wysoki stopień specjalizacji i bliskie powiązanie z jednym sektorem zaobserwowano w przypadku Doniecka, Bukaresztu, Kijowa i Bratysławy. 
Najwyższe wartości wskaźnika stabilności odnotowano dla Warszawy, Pragi i Budapesztu, przy czym wzrost w okresie objętym badaniem odnotowała tylko Praga, podczas gdy w przypadku Warszawy i Budapesztu zauważono spadek. Pozostałe miasta o rosnącym wskaźniku stabilności to miasta o najniższych wartościach wskaźnika: Wrocław, Ryga, Trójmiasto i Toruń (rycina 1).

Analiza głównych składników dowodzi, że najsilniej na wartość CEEŚW wpływał wskaźnik stabilności (około 83,3\% przypadków w 2008 roku i 79,22 przypadków w 2015 roku) oraz liczba sektorów (15,88\% w 2008 roku i 18,88\% w 2015 roku). Największa różnica w stosunku do średniej standaryzowanej wartości dla tych dwóch głównych zmiennych dotyczy Warszawy, Pragi i Budapesztu, szczególnie widoczne było to w przypadku wskaźnika stabilności (rycina 1). Warszawa pozostaje liderem we wszystkich badanych latach pod względem wartości SI i liczby sektorów. Dopiero w 2012 roku Łódź i Nove Mesto zwiększyły liczbę sektorów. Było to prawdopodobnie spowodowane trwającym od 2008 roku kryzysem gospodarczym, który najbardziej dotknął największe miasta o największej liczbie powiązań z globalnym kapitałem i światowymi rynkami. Z tego samego powodu wzrosła względna pozycja Bukaresztu. Wydaje się, że w latach 2008-2015 model został zakłócony przez kryzys gospodarczy z 2008 roku. Wzór w 2015 roku przybrał postać funkcji malejącej $\left(\mathrm{SI}_{1}<\mathrm{SI}_{2} f\left(S I_{1}\right)>f\left(S_{2}\right)\right)$. $\mathrm{Z}$ jednej strony mamy Dniepropietrowsk, Donieck i Ostrawę, a z drugiej strony Pragę i Budapeszt. Tylko Warszawa i Tallinn pozostają poza tym wzorcem na przeciwległych krańcach spektrum.

Najwyższe wartości CEEŚW w 2008 roku odnotowano dla Warszawy (4,7pkt), Budapesztu (2,5 pkt) i Pragi (2,4 pkt) (rycina 2). Odporność na kryzys w głównym sektorze gospodarki Budapesztu spadła w 2012 i 2015 roku, co doprowadziło do spadku jego pozycji w stosunku do Pragi i Warszawy. Pozostałe stolice charakteryzowały się także dość wysokim poziomem CEEŚW w 2015 roku: Bratysława $(1,99)$, Bukareszt $(1,94)$, Lublana $(1,46)$. Z drugiej strony pozycja Kijowa znacznie się obniżyła. W 2008 roku CEEŚW wynosił 1,42, podczas gdy w 2015 roku wartość ta była o $40 \%$ mniejsza. Najniższe wartości (poniżej 0,5) dla miast CEEŚW w badanym okresie odnotowały Pardubice, Braszów i Tallinn. Największe wzrosty odnotowały natomiast mniejsze miasta, np. Łódź (240\%), Novo Mesto (189\%), Poznań (176\%), Pardubice (158\%) czy Kraków (153\%). Jednak tylko Poznań przekroczył w 2015 roku wartość 1 pkt. Kilka miast zostało sklasyfikowanych jako miasta CEEŚW tylko w ciągu jednego okresu badań. Były to: Ryga, Wrocław, Donieck, Ostrawa, Pardubice i Dniepropietrowsk.

Warszawa, Praga i Budapeszt są najsilniejszymi Centrami Ekonomicznymi Europy Środkowo-Wschodniej. Jednak tylko Praga miała na swym terenie firmy należące do wszystkich dziewięciu sektorów (Warszawa i Budapeszt mają po osiem sektorów). Wiodące miasta różnią się również pod względem dominującego sektora. W Warszawie jest nim konsumencki i transportowy, w Pradze energetyczny i surowcowy, a w Budapeszcie produkcyjny. Bratysława, Bukareszt, Lublana, Zagrzeb, Poznań i Katowice również zostały zaklasyfikowane do głównych CEEŚW, jednak odporność ich funkcji kontrolno-zarządczej na kryzys jest mniejsza niż wyraźnie dominującej Warszawy, Pragi i Budapesztu. W Grupie CEEŚW jedynie Poznań i Katowice nie są miastami stołecznymi, jednakże występują w silnie rozwiniętych, pod różnymi względami, regionach Polski (Winiarczyk-Raźniak, Raźniak, 2011; Raźniak, Winiarczyk-Raźniak, 2014; Páthy, 2017). W analizowanym regionie najwięcej miast jest położonych w Polsce (39\%), nie są one jednak zróżnicowane pod względem dominującego sektora i przeważa w tym 
Rycina 1. Różnice średnich wartości standardowych wskaźnika stabilności i liczby sektorów w latach 2008 i 2015

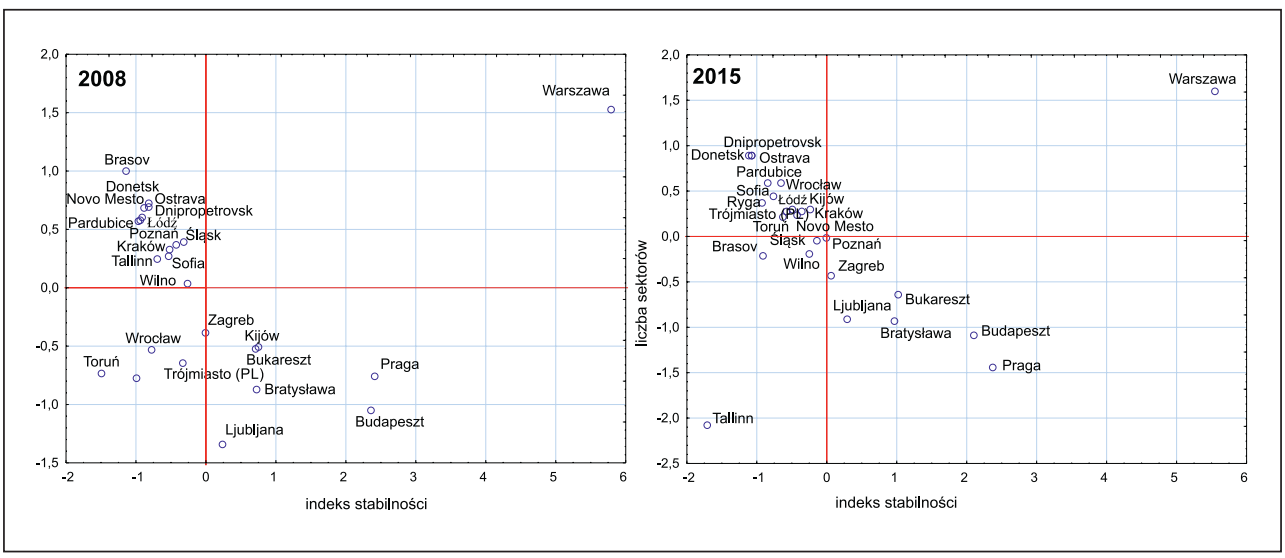

Źródło: opracowanie własne na podstawie Deloitte Top 500 Reports (Deloitte, 2018)

Rycina 2. Centra Ekonomiczne Europy Środkowo-Wschodniej w 2015 roku

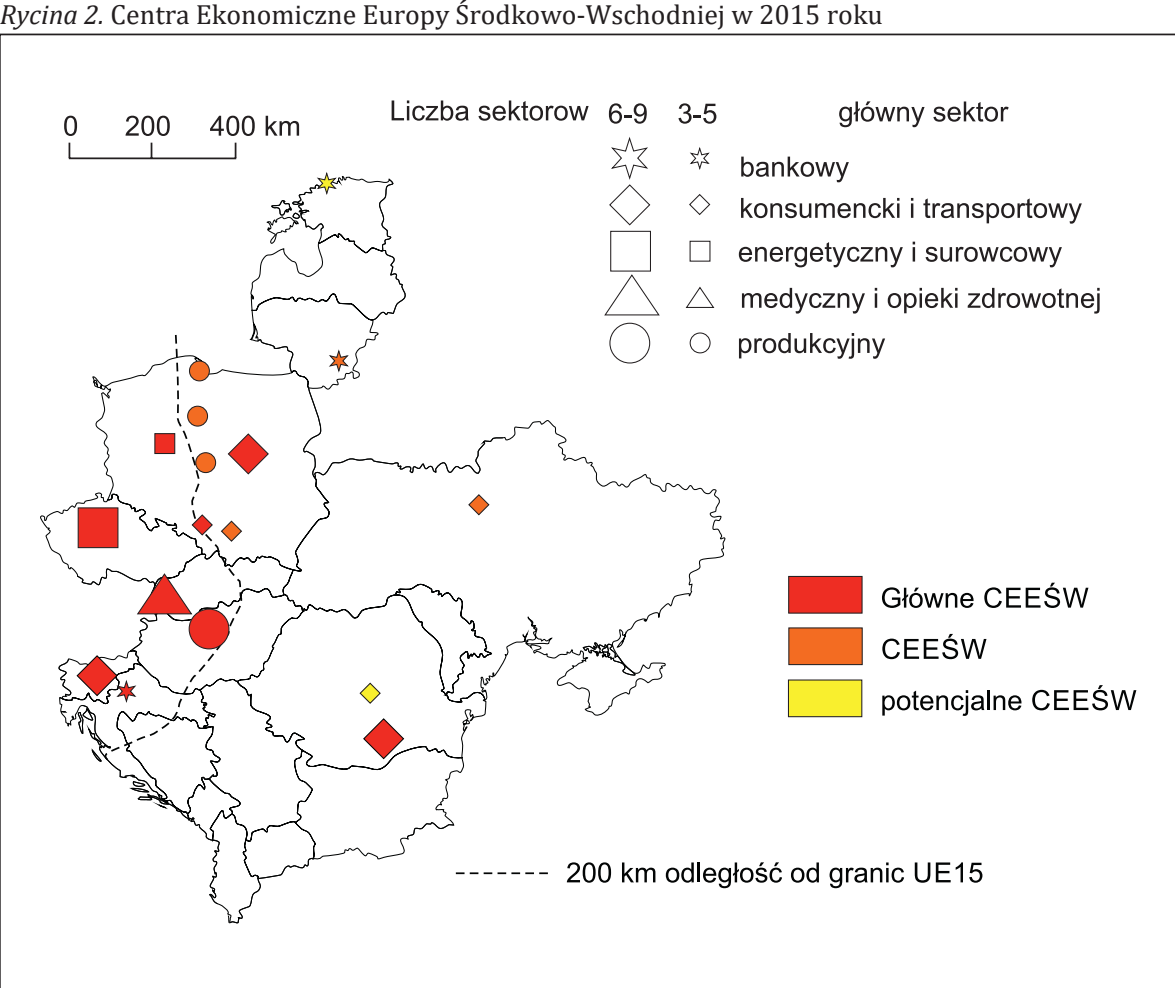

Źródło: opracowanie własne na podstawie Deloitte Top 500 Report (Deloitte, 2018)

przypadku sektor medyczny i opieki zdrowotnej oraz konsumencki i transportowy. Wśród potencjalnych CEEŚW znalazły się Braszów i Tallinn.

Wśród analizowanych miast najczęściej dominował sektor konsumencki i transportowy, występujący w ośmiu miastach (44\%). Reprezentowany był głównie w byłych 
republikach radzieckich: na Litwie, Łotwie, Estonii i Ukrainie. Sektor produkcyjny przeważał w czterech miastach (22\%), głównie w starych okręgach przemysłowych, takich jak np. Trójmiasto i Łódź (22,2\%). Generalnie CEEŚW zdominowane były przez sektor konsumencki i transportowy oraz produkcyjny (66\% miast).

\section{PodsumoWANIE}

Najmniej Centrów Ekonomicznych Europy Środkowo-Wschodniej zanotowano w krajach byłej Jugosławii (Lublana i Zagrzeb). Niewielka liczba dużych firm na tym terenie może być związana ze skutkami wojny domowej mającej miejsce w latach dziewięćdziesiątych XX wieku, a działania wojenne i tworzenie nowych granic nie sprzyjają wzrostowi gospodarczemu. Obecna dominacja Lublany i Zagrzebia może wynikać z relatywnego braku działań militarnych na tym obszarze w latach dziewięćdziesiątych, co przyspieszyło postęp gospodarczy po zaprzestaniu działań wojennych. Obydwa miasta znajdują się jednocześnie w odległości mniejszej niż 100 km od Włoch i Austrii, które należą do najlepiej rozwiniętych krajów Unii Europejskiej.

Generalnie zauważono wpływ byłego Związku Radzieckiego na przestrzenne rozmieszczenie Centrów Ekonomicznych Europy Środkowo-Wschodniej. Największa ich liczba znajduje się w krajach, które po II wojnie światowej były osobnymi państwami, aczkolwiek znajdowały się pod silnym wpływem politycznym i gospodarczym ZSRR. Jednocześnie większość z tych państw znajduje się w pobliżu granic UE 15. Z kolei miasta byłych republik radzieckich, które obecnie stanowią osobne państwa (często pozostające pod dużym wpływem Rosji), charakteryzują się niższą odpornością na kryzys funkcji kontrolno-zarządczej. Jednocześnie położone są w stosunkowo dużej odległości od krajów UE 15.

Podczas gdy specjalizacja gospodarcza oraz rozwój klastrów może służyć jako podstawowe narzędzie rozwoju gospodarki na poziomie lokalnym lub regionalnym (Bański i in., 2013; Dziemianowicz, Szlachta, Peszat, 2014), należy zauważyć, że bardzo wąska specjalizacja gospodarcza może być bardzo niekorzystna dla miasta, które boryka się z transformacyjnymi zmianami technologicznymi lub światowym kryzysem gospodarczym (Dorocki, 2012; Gawlikowska-Hueckel, Szlachta, 2014; Raźniak, Dorocki, Winiarczyk-Raźniak, Płaziak, Szymańska, 2016). Opieranie gospodarki miejskiej na bardzo wąskim sektorze stwarza ryzyko upadku ekonomicznego, jeśli główny sektor ulegnie trwałemu spadkowi lub dotknięty zostanie poważnym kryzysem gospodarczym. Wydaje się, że miasta o zdywersyfikowanej gospodarce lokalnej są bardziej odporne na wahania koniunktury niż miasta o gospodarkach opartych na jednym sektorze. Przydatne jest przytoczenie takich przykładów, jak miasto Łódź (Jakóbczyk-Gryszkiewicz, 2011) w Polsce oraz Pittsburgh w Stanach Zjednoczonych (Duranton, Puga, 2000), gdzie spadek jednego dużego sektora spowodował ogólną stagnację gospodarczą w obu przytaczanych regionach. To samo może dotyczyć miast, w których mieszczą się duże korporacje. Miasta z siedzibą firm z różnych sektorów gospodarki rzadziej doświadczają kryzysu gospodarczego związanego z zarządzaniem i kontrolą niż kraje z jednym dominującym sektorem gospodarki. Miasta takie jak Sofia, Belgrad i Ryga funkcjonują jako stolice państwowe, ale nadal muszą wspierać swoją dywersyfikację gospodarczą, aby gromadzić większą liczbę sektorów gospodarki. Mimo wykonywania funkcji zarządzania i kontroli (Raźniak, Dorocki, 
Winiarczyk-Raźniak, 2018a) miasta te nie są odporne na kryzys, który może dotknąć ich główny sektor gospodarczy.

Generalnie można stwierdzić, że brak dominującego sektora finansowego może być kluczową siłą gospodarki Centrów Ekonomicznych Europy Środkowo-Wschodniej. Podczas gdy w okresie dobrej koniunktury gospodarczej sektor finansowy może napędzać wzrost, to może również spowodować załamanie gospodarcze w czasie spowolnienia gospodarczego (Sassen, 2011). Główne miasta w Europie Środkowo-Wschodniej mają dosyć słabe powiązania globalne przez co mogą być odporne na kryzysy na światowych rynkach finansowych. Ponadto mają one silny „efekt bociana”, dosyć skutecznie opierając się kryzysowi funkcji kontrolno-zarządczej. Efekt ten można również zaobserwować w światowej gospodarce (Raźniak, Dorocki, Winiarczyk-Raźniak, 2017).

\section{Literatura \\ References}

Alderson, A., Beckfield, J. (2004). Power and position in the world city system. American Journal of Sociology, 109(4), 811-851.

Bański, J., Czapiewski, K., Ferenc, M., Mazur, M., Konopski, M., Solon, B. (2013). Badanie potencjałów i specjalizacji województwa podkarpackiego. Raport. Warszawa: Instytut Geografii i Przestrzennego Zagospodarowania Polskiej Akademii Nauk.

Chojnicki, Z., Czyż, T. (1978). Podstawy metodologiczne zastosowania analizy czynnikowej. W: Z. Chojnicki, T. Czyż, J. Parysek, W. Ratajczak (red.). Badanie przestrzennej struktury społeczno-ekonomicznej Polski metodami czynnikowymi. Poznań-Warszawa: Wydawnictwo Naukowe PWN.

Csomós, G. (2013). The Command and Control Centers of the United States (2006/2012): An Analysis of Industry Sectors Influencing the Position of Cities. Geoforum, 12(50), 241-251. doi: 10.1016/j.geoforum.2013.09.015

Csomós, G. (2017). Cities as command and control centres of the world economy: An empirical analysis, 2006-2015. Bulletin of Geography. Socio-economic Series, 38, 7-26. doi: 10.1515/ bog-2017-0031

Csomós, G., Derudder, B. (2014). Ranking Asia-Pacific cities: Economic performance of multinational corporations and the regional urban hierarchy. Bulletin of Geography. Socio-economic series, 25, 69-80. doi: 10.2478/bog-2014-0030

Deloitte (2018, 19 marca). Pozyskano z www.deloitte.com

Derudder, B., Cao, Z., Liu, X., Shen, W., Dai, L., Zhang, W., Caset, F., Witlox, F., Taylor, P. (2018). Changing Connectivities of Chinese Cities in the World City Network, 2010-2016. Chinese Geographical Science, 28(2), 183-201. doi: 10.1007/s11769-018-0938-6

Dorocki, S. (2012). Regional differentiation in the development of French towns-quantitative analysis. Barometr Regionalny, 3(29), 13-31.

Dorocki, S., Raźniak, P., Winiarczyk-Raźniak, A. (2019). Changes in the command and control functions of European cities in 2006-2016. Geographia Polonica, 92(3) (w druku).

Drobniak, A. (2017). Economic resilience and hybridization of development - A case of the Central European Regions. Regional Statistics, 7(1), 43-62. doi: 10.15196/RS07103

Duranton, G., Puga, D. (2000). Diversity and specialization in cities: why, where and when does it matter? Urban Studies, 37(3), 533-555.

Dziemianowicz, W., Szlachta, J., Peszat, K. (2014). Potencjały rozwoju i specjalizacje polskich województw. Warszawa: Ministerstwo Infrastruktury i Rozwoju.

Forbes Global 2000 (2018, 15 lutego). Pozyskano z www.forbes.com

Gawlikowska-Hueckel, K., Szlachta, J. (2014). Wrażliwość polskich regionów na wyzwania współczesnej gospodarki. Implikacje dla polityki rozwoju regionalnego. Warszawa: Wolters Kluwer Polska.

Globalization and World Cities (2018, 19 marca). Pozyskano z www.lboro.ac.uk 
Jakóbczyk-Gryszkiewicz, J. (2011). Łódź u progu XXI wieku. Studia Miejskie, 4, 131-138.

Kilar, W. (2015). Settlement concentration of economic potential represented by IT corporations. Geographia Polonica, 88(1), 123-141. doi: 10.7163/GPol.0009

Maćkiewicz, A.J, Ratajczak, W. (1993). Principal components analysis (PCA). Computers and Geosciences, 19(3), 303-342. doi: 10.1016/0098-3004(93)90090-R

Masik, G. (2016). Economic resilience: The case of Poland and certain European regions. Geographia Polonica, 89(4), 457-471. doi: 10.7163/GPol.0068

Morrison, D. (1967). Multivariate statistical methods. New York: McGrawHill.

Parysek, J., Ratajczak, W. (2002). Analiza składowych głównych, jej korzyści i ograniczenia z punktu widzenia badań geograficznych. W: H. Rogacki (red.). Możliwości i ograniczenia zastosowania metod badawczych w geografii i gospodarce przestrzennej. Poznań: Bogucki Wydawnictwo Naukowe, 61-73.

Páthy, Á. (2017). Types of development paths and the hierarchy of the regional centres of Central and Eastern Europe. Regional Statistics, 7(2), 124-147. doi: 10.15196/RS070202

Raźniak, P., Dorocki, S., Winiarczyk-Raźniak, A. (2015). Ranga miasta w świetle syntetycznego wskaźnika stabilności gospodarczej. Studia Miejskie, 18, 119-130.

Raźniak, P., Dorocki, S., Winiarczyk-Raźniak, A. (2017). Permanence of the economic potential of cities based on sector development. Chinese Geographical Science, 1(27), 123-136. doi: 10.1007/s11769-017-0850-5

Raźniak, P., Dorocki, S., Winiarczyk-Raźniak, A. (2018a). Eastern European cities as command and control centres in time of economic crisis. Acta Geographica Slovenica, 58(2), 101-110. doi: 10.3986/AGS.3124

Raźniak, P., Dorocki, S., Winiarczyk-Raźniak, A. (2018b). Światowe centra ekonomiczne w Stanach Zjednoczonych - stan obecny i perspektywy rozwoju. Prace Komisji Geografii Przemysłu Polskiego Towarzystwa Geograficznego, 32(3), 116-127. doi 10.24917/20801653.323.7

Raźniak, P., Dorocki, S., Winiarczyk-Raźniak, A., Płaziak, M., Szymańska, A.I. (2016). Lokalizacja ośrodków kontroli i zarządzania elementem stabilności gospodarczej ośrodków miejskich w Europie Środkowo-Wschodniej. Prace Komisji Geografii Przemysłu Polskiego Towarzystwa Geograficznego, 2(30), 38-54.

Raźniak, P., Dorocki, S., Winiarczyk-Raźniak, A., Płaziak, M., Szymańska, A.I. (2017). Zmiany pozycji ekonomicznej miast Europy Środkowo-Wschodniej w przypadku kryzysu dominującego sektora. Ekonomista, 2017(1), 67-83.

Raźniak, P., Winiarczyk-Raźniak, A. (2014). Influence of the societal security level on population migrations in Poland. Procedia - Social and Behavioral Sciences, 120, 2-12. doi: 10.1016/j. sbspro.2014.02.075

Raźniak, P., Winiarczyk-Raźniak, A. (2015). Did the 2008 global economic crisis affect large firms in Europe? Acta Geographica Slovenica, 55(1), 127-139. doi: 10.3986/AGS.740

Sassen, S. (1991). The Global City: New York, London, Tokyo. Princeton: Princeton University Press. Sassen, S. (2006). Cities in a world economy. 3rd Edition. Pine Forge Press: Thousand Oaks.

Sassen, S. (2011). Cities in a World Economy, fourth edition. Sage Publications.

Sassen, S. (2016). The Global City: Enabling Economic Intermediation and Bearing Its Costs. City and Community, 15(2), 97-108. doi: 10.1111/cico.12175

Śleszyński, P. (2015). Economic control functions in Poland in 2013. Geographia Polonica, 88(4), 701-708. doi: 10.7163/GPol.0041

Śleszyński, P. (2018). Research Topics of Geography of Enterprise and Decision-Control Functions in Poland against Global Trends. Prace Komisji Geografii Przemysłu Polskiego Towarzystwa Geograficznego, 32(4), 23-47. doi: 10.24917/20801653.324.2

Taylor, P., Ni, P., Derudder, B., Hoyler, M., Huang, J., Lu, F., Pain, K., Witlox, F., Yang, X., Bassens, D., Shen, W. (2009). The Way We Were: Command and Control Centres in the Global SpaceEconomy on the Eve of the 2008. Environment and Planning A, 41(1), 7-12. doi:10.1068/ a41318

Winiarczyk-Raźniak, A., Raźniak, P. (2011). Regional differences In the standard of living in Poland (based on selected indices). Procedia - Social and Behavioral Sciences, 19, 31-36.

Zdanowska, N. (2017). Distribution of foreign direct investment across the national urban system in countries of Central and Eastern Europe in 2013. Geographia Polonica, 90(2), 5-24. doi: https://doi.org/10.7163/GPol.0084 
Piotr Raźniak, dr, Uniwersytet Pedagogiczny w Krakowie, Wydział Geograficzno-Biologiczny, Instytut Geografii, Zakład Geografii Społeczno-Ekonomicznej. Do jego zainteresowań badawczych należą problemy gospodarcze miast, hierarchie miast światowych, problemy funkcjonowania obszarów metropolitalnych oraz funkcje kontrolno-zarządcze miast kreowane przez korporacje.

Piotr Raźniak, PhD, Pedagogical University of Krakow, Faculty of Geography and Biology, Institute of Geography, Department of Socio-Economic Geography. His research interests include: corporations, hierarchies of world cities, problems of the functioning of metropolitan areas, spatial structure of corporations and command and control functions of cities created by large corporations.

ORCID: 0000-0001-9757-7022

\title{
Adres/address:
}

\author{
Uniwersytet Pedagogiczny w Krakowie \\ Instytut Geografii \\ Zakład Geografii Społeczno-Ekonomicznej \\ ul. Podchorążych 2, 30-084 Kraków, Polska \\ e-mail: piotr.razniak@up.krakow.pl
}

Sławomir Dorocki, dr, Uniwersytet Pedagogiczny w Krakowie, Wydział Geograficzno-Biologiczny, Instytut Geografii, Zakład Geografii Społeczno-Ekonomicznej. Dr nauk humanistycznych w dyscyplinie historia (Instytut Europeistyki, Uniwersytet Jagielloński), adiunkt w Instytucie Geografii Uniwersytetu Pedagogicznego w Krakowie, absolwent studiów z zakresu geografii społeczno-ekonomicznej Uniwersytetu Pedagogicznego w Krakowie. Zainteresowania badawcze skupiają się wokół problematyki regionów i procesów regionalizacji społeczno-gospodarczej, ze szczególnym uwzględnieniem zróżnicowania przestrzeni europejskiej oraz procesów integracji europejskiej i uwarunkowań historycznych, oraz zastosowania metod komputerowych i statystycznych w badaniach nad zróżnicowaniem przestrzeni.

Sławomir Dorocki, PhD, Pedagogical University of Krakow, Faculty of Geography and Biology, Institute of Geography, Department of Socio-Economic Geography. Associate professor at the Pedagogical University of Krakow, Institute of Geography. He has graduated from the Pedagogical University of Krakow, holds an MA degree in Geography and a PhD in History (Institute of European Studies of the Jagiellonian University). His research interests are connected to regional problems and processes of socio-economic regionalisation, with particular emphasis on the diversity of Europe, processes of European integration, historical conditions, and application of computer and statistical methods in the study of diversity of space.

ORCID: 0000-0001-6083-0346

\section{Adres/address:}

\author{
Uniwersytet Pedagogiczny w Krakowie \\ Instytut Geografii \\ Zakład Geografii Społeczno-Ekonomicznej \\ ul. Podchorążych 2, 30-084 Kraków, Polska \\ e-mail: sdorocki@up.krakow.pl
}

Anna Winiarczyk-Raźniak, dr, Uniwersytet Pedagogiczny w Krakowie, Wydział Geograficzno-Biologiczny, Instytut Geografii, Zakład Geografii Społeczno-Ekonomicznej. Do jej zainteresowań badawczych należy geografia społeczna Ameryki Łacińskiej, w szczególności zróżnicowanie etniczno-kulturowe, turystyka w Ameryce Łacińskiej oraz hierarchie miast światowych i funkcje kontrolno-zarządcze miast kreowane przez korporacje.

Anna Winiarczyk-Raźniak, PhD, Pedagogical University of Krakow, Faculty of Geography and Biology, Institute of Geography, Department of Socio-Economic Geography. Her research interests include: social geography of Latin American countries, especially ethnic and cultural composition, tourism in Latin America and hierarchies of world cities and command and control functions of cities created by large corporations.

ORCID: 0000-0002-5276-5297 
Adres/address:

Uniwersytet Pedagogiczny w Krakowie

Instytut Geografii

Zakład Geografii Społeczno-Ekonomicznej

ul. Podchorążych 2, 30-084 Kraków, Polska

e-mail: anna.winiarczyk-razniak@up.krakow.pl 